\title{
Trade Openness and Economic Growth: A Review of the Literature
}

\author{
Muhammad Tahir ${ }^{1} \&$ Dr. Dk Hajah Norulazidah Binti Pg Haji Omar Ali ${ }^{1}$ \\ ${ }^{1}$ School of Business and Economics, Universiti Brunei Darussalam, Brunei \\ Correspondence: Muhammad Tahir, School of Business and Economics, Universiti Brunei Darussalam, Jalan \\ Tungku Link BE-1410, Bandar Seri Begawan, Brunei. Tel: 673-860-1952. E-mail: mtahir0086@gmail.com
}

\author{
Received: February 18, 2014 Accepted: March 20, 2014 Online Published: April 29, 2014 \\ doi:10.5539/ass.v10n9p137 URL: http://dx.doi.org/10.5539/ass.v10n9p137
}

\begin{abstract}
This study surveys the available empirical literature on the relationship between trade openness and economic growth. The motivation to the current study stems from the persistent conflicting results mostly on the empirical side, which have created confusion among the researchers and policy makers over the trade-growth relationship. Overall, this paper concludes that the available literature provides an affirmative answer to the question whether or not trade openness causes economic growth. However, various issues still exist in the current literature, which need appropriate approach to handle them, in order to establish an explicit relationship between trade openness and economic growth.
\end{abstract}

Keywords: literature, trade openness, economic growth, endogeneity, policies

\section{Introduction}

Researchers have employed various econometric tools on different objective and subjective measures of trade openness during the last few decades in order to ascertain a robust relationship between trade openness and economic growth. The compelling message from literature is that indeed there is a positive relationship between trade openness and economic growth. The phenomenal growth performances of the Asian Tigers (Singapore, Taiwan, Hong Kong, South Korea) over the years and the recent growth experiences of the giant economies of India and China have brought significant changes in policies especially in the developing world regarding foreign trade. Panagariya (2004) argues that the last fifty years of experience provides sound support to the case of free trade. Various issues, however, still exist in the current literature, which need appropriate approach to handle them, in order to establish an explicit relationship between trade openness and economic growth. However, the existence of such issues does not indicate that the observed relationship between trade openness and economic growth is fragile. Fiestas (2005) have rightly argued that despite methodological issues, there is no evidence that trade liberalization is harmful for economic growth. The benefits associated with outward-oriented policies are quite visible and have been widely accepted by both researchers and policy makers.

Different factors can explain why researchers have not been able to provide an explicit answer to the question of whether trade openness really matters for achieving a higher economic growth. Firstly, the measures of trade openness used in the earlier studies and the methodologies used to estimate models that link openness to growth are still open to doubt (Huchet-Bourdon et al., 2011). Over the years, researchers have employed various tools of analysis on different objective and subjective indices of openness in order to establish an explicit relationship between trade openness and economic growth. These developments in the literature have further complicated things for the researcher to select appropriate econometric techniques and appropriate proxies for trade openness in the analysis. Greenaway et al., (2002) have documented that the use of diverse indices of liberalization coupled with the problem of miss-specification could be responsible of the inconsistent evidence regarding the growth effects of liberalization. Secondly, a clear cut mechanism by which trade openness influences economic growth is ambiguous. Hallak and Levinsohn (2004) have rightly emphasized that future research efforts shall focus on identifying the mechanisms by which trade openness influences economic growth. More to the point, Wald and Wood (2004) have commented that very little is known about the links of trade policy and economic growth. Therefore, one cannot rely on theoretical framework because theories do not provide a decisive answer to the trade-growth relationship as mentioned by Ulasan (2012). The only option researchers do have is to deal with the trade - growth relationship empirically. Thirdly, the poor quality of data especially in the context of low-income developing countries, sample heterogeneity and the presence of non-linearity in the trade-growth nexuses can explain up to some extent the observed disagreement over the trade-growth relationship among the 
researchers. The inclusion of countries into sample that differs significantly in terms of economic parameters and the poor quality of data can lead to the problem of generalizability. Therefore, researchers must pay greater attention to ensure the reliability of data and also the sample under consideration is homogeneous in terms of economic parameters.

The current survey analyzes the available empirical research regarding the trade-growth relationship. Such exercises provide guidelines for the potential researchers to re-think on the trade-growth relationship and contribute to the literature by exploring the new insights which are ignored in the available literature. Policy makers would also benefit significantly if an explicit relationship between trade openness and economic growth is established. Some researchers such as Hallak and Levinsohn (2004), Ulasan (2012) and Dava (2012) believe that the available literature is not exhaustive to produce an acceptable conclusion regarding the trade-growth relationship. Furthermore, the evidence in favor of a positive relationship prevailing between trade openness and growth has been criticized by Rodrik and Rodriguez (2001) and Rodriguez (2007).

The rest of the survey is organized as follows. Section two of the paper examines the relationship between trade openness and economic growth from empirical point of view. Issues with the literature are discussed and analyzed in the penultimate section. The last section of the paper presents concluding remarks.

\section{Empirical Literature}

\subsection{Early Evidence (1990-2000)}

Studies carried out during 1990-2000 have provided concrete evidence in favor of a positive impact that trade openness has had on economic growth. Starting from Dollar (1992), who proposed two indices (real exchange rate distortion index and real exchange rate variability) for measuring trade liberalization and reported that open economies grew remarkably faster compared to closed economies during the period 1976-1985. The author suggests the developing countries to speed up the process of trade liberalization from growth perspective. Sachs and Warner (1995) further provide solid evidence about the positive trade-growth nexus and empirically demonstrated that open developing economies have grown at 4.49 percent per year while at the same time open developed economies have grown at 2.29 percent per year. On the other hand, closed developing and developed economies have grown at 0.69 and 0.74 percents per year respectively.

Edwards (1998) tries to capture different channels through which policy makers can protect their economies from foreign competition. He shows that total factor productivity growth is higher for open economies. In his study, he claims that the findings are robust to functional form, measures of trade openness, method of estimation and time period. Frankel and Romer (1999), primarily focus on the endogeneity issue associated with the trade-volume measure of openness by utilizing information from the well-known gravity model of international trade. They find that there is a positive relationship between actual trade openness, instrumented trade openness and economic growth. These findings suggest that the causality is running from trade openness to economic growth instead of the other way round (Willard, 2000).

The dominant message from the empirical literature during 1990-2000 is that indeed there exists a positive relationship between trade openness and economic growth. Also, this positive relationship between trade openness and growth was not only robust to the indicators of openness but also to functional form, estimation techniques and time period as claimed by Edwards (1998). Further, the novel work of Frankel and Romer (1999) has addressed the endogeneity issue associated with the trade-volume measure of openness by utilizing information from the well-know gravity model of international trade. These developments in the literature have changed the perception of both policy makers and researchers in favor of a positive relationship that exists between trade openness and economic growth.

\subsection{Critics to Early Evidence}

The positive relationship between trade openness and economic growth reported during 1990-2000 was widely accepted and the literature was moving towards a general conclusion. However, the literature opened to doubts with the publication of a comprehensive critical paper titled "Trade Policy and Economic Growth: A Skeptic's Guide to the Cross-National Evidence" of Rodrik and Rodriguez (2000). The study has criticized the measures of openness used by Dollar (1992) and Sachs and Warner (1995) on various grounds. They have also put doubts on the applied methodology used by Edwards (1998) and the instrumentation strategy employed by Frankel and Romer (1999). It follows that the positive relationship between trade openness and economic growth reported during 1990-2000 was either due to inappropriate econometric techniques employed or due to the flawed measures of openness used in the earlier studies.

The earlier evidence (1990-2000) in favor of a positive relationship between trade openness and economic 
growth became doubtful after the convincing criticism of Rodrik and Rodriguez (2000). Therefore, the debate about the trade-growth relationship was seems far from reaching a general conclusion and the question, whether trade openness has any impact on economic growth is yet to find a consensus answer.

\subsection{Support to Early Evidence (2000-2005)}

Free trade supporters have attempted to analyze the criticism about the positive trade-growth relationship reported in the study of Rodrik and Rodriguez (2000). Warner (2003) dismisses the criticism of Rodrik and Rodriguez (2000) on the positive link between trade openness and growth. He argues that they have ignored the crucial evidence and indeed there is a negative relationship between trade restrictions and economic growth. Jones (2000) have also shared the similar view and commented that trade restrictions are harmful to long run incomes. Panagariya (2004), analyzes the criticism made by Rodrik and Rodriguez (2000) and concludes that the evidence from cross - country growth regression is not weak and therefore, outward-oriented policies cannot be rejected. Further, the scholar argues that controversies arise because of our inabilities to measure the protective effects of a given set of trade barriers. Bhagwati and Srinivasan (2001) have also analyzed the criticism of Rodrik and Rodriguez (2000) and assert that their criticism is unpersuasive. Fiestas (2005) contends that despite methodological issues, there is no evidence that trade liberalization is harmful for economic growth. Wacziarg and Welch (2003) find that the annual growth rates were 1.5 percentage points higher for countries with liberalized trade policies after trade liberalization over the period 1950-1998. These consequent studies have attempted to get rid of the confusion created by the criticism of Rodrik and Rodriguez (2000) among the researchers and policy makers regarding the positive impact of trade openness on economic growth.

\subsection{Recent Evidence}

Edwards (1998) rightly comments that controversies never die. Rodriguez (2007) criticizes the literature responding to the early criticism of Rodrik and Rodriguez (2000). Rodriguez's work (2007) critically evaluates the subsequent research papers of Warner (2003), Wacziarg and Welch (2003) and Dollar and Kraay (2002) and holds the view that standard measures of trade policy are not correlated with economic growth. However, he argues that the positive or negative relationship between trade openness and growth may exist but the data do not have strong information to be picked up. It implies that the disagreement is not about the existence or absence or positive or negative relationship between trade and growth. It is rather about the use of new tools which could successfully pick information from the data even if such information is not very strong. The simple regression framework is too simple to capture the relationship between trade policy and economic growth (Hallak \& Levinsohn, 2004).

Krueger and Berg (2003) analyze the literature regarding the trade-growth relationship compressively by focusing on; cross country and panel regressions, industry and firm level research and case studies. In their study, it is concluded that trade influences economic growth. Winters (2004) also lends support to the argument by concluding that trade openness enhances economic growth at least over the medium term. However, various issues do exist. Lopez (2005) surveys the literature and concludes that the empirical research on plant level data shows that trade liberalization can enhance productivity and economic growth in the developing countries. Similarly, recently, Babula and Anderson (2008) conclude that there is a likely positive relationship between international trade and economic growth. They are, however, concerned with the ability of the developing countries to gain productivity growth by using trade liberalization and the way endogeneity and measurement issues are addressed in empirical studies. Bruckner and Lederman (2012) found that a one percent increase in openness impact the short run economic growth and the long run economic growth by 0.5 and 0.8 percent per year respectively.

According to Mendoza (2010), the track record of trade openness and economic growth is mixed and the relationship between trade openness and the economic growth is conditional. Stone and Strutt (2009) hold the view that trade is an important driver of growth and infrastructure is a necessity of trade. It follows that good policies towards other sectors of the economy are important to implement in order to reap the full benefits of liberalization process. Chang et al., (2005) documented that the impact of increased openness on economic growth will be higher if the process is supported by higher investment in human capital, deeper markets and with the availability of infrastructure. Cuadros et al., (2004) have considered both trade and financial liberalization as indicators of openness. Therefore, appropriate policies towards foreign direct investment shall be implemented. It seems utmost importance to focus on complementary policies in order to grab the full benefits of trade liberalization.

In general, the dominant message from the recent literature is that indeed there is a likely positive relationship between trade openness and economic growth. Krueger and Berg (2003) and Babula and Anderson (2008) have 
also concluded that trade openness causes economic growth. However, they have collectively indentified some contending issues attached with current empirical literature. In the following section, we discuss some well-known issues with the literature that need to be addressed appropriately in order to suggest a concluding consensus regarding the impact of trade openness and economic growth. These issues emanated from the observed disagreements among the researchers about the trade-growth link.

\section{Issues with the Literature}

\subsection{Measure of Trade Openness}

How to define and measure the degree of trade openness of an economy is indeed a tough task and is a common problem associated with cross-country studies (Winters, 2004). According to Alcala and Ciccone (2003), trade openness can be measured in different ways. It is difficult to construct a universally acceptable measure of trade openness. Various contending measures of openness such as trade intensity, tariff and non-tariff barriers, the indices constructed by Dollar (1992) and Sachs and Warner (1995) are available to potential researchers. However, Rodriguez (2000) and David (2007) among others have serious reservations on various grounds over the use of the mentioned indices for openness.

We can also measure the degree of openness of an economy through a different angle, if we assume that only open economies can access to foreign advanced technologies and investment goods. Foreign capital and intermediate goods, which embody superior technology, enhance productivity growth in the sector using this product (Das, 2002). Dollar (1992) argues that outward-oriented policies provide opportunities to economies to use external capital for development purpose. Therefore, foreign advanced technologies and investment goods flourish the manufacturing activities in the domestic economy and in turn the contribution of manufacturing sector to the GDP increases. In this way, one can also use the ratio of manufacturing output to GDP as a measure of openness.

Real effective exchange rate could also be considered while studying the relationship between trade openness and economic growth. In fact openness and real effective exchange rate are closely related. When real effective exchange rate increases, it is the indication of real depreciation of local currency relative to foreign currencies. Depreciation of the local currency stimulates exports and hence growth rate is also influenced positively. Even though import volume decreases, the value of imports increases in domestic currency terms because the currency has depreciated. Only rarely will the volume effect be greater than the currency effect. In a sense real effective exchange rate indirectly measures trade openness. Higher real effective exchange rate is associated with higher openness and vice versa.

Based on the available empirical literature known to the authors, manufacturing output as a ratio of GDP and real effective exchange rate have not been used in the literature for measuring the degree of trade openness. Therefore, the use of these measures in the empirical work will be useful and interesting.

\subsection{The Endogeneity Issue}

The endogeneity issue has not been appropriately handled yet, and it is not clear whether trade is causing growth or growth is causing trade or the relationship is bi-directional (Babula \& Anderson, 2008). Frankel and Romer (1999) have handled the endogeneity issue associated with the trade-volume measure of openness by utilizing information from the well-known gravity model of international trade. Rodrik and Rodriguez (2000), criticize the instrumentation strategy of Frankel and Romer (1999) by arguing that the constructed instrument measures the non-trade effects of geography on income.

However, one could still use the geography based instrument of openness following the procedure suggested by Noguer and Siscart (2005) in order to ensure more accuracy and precision in its construction. Similarly, some useful modification could also be done in the framework of Frankel and Romer (1999) by converting area and population into population density in order to increase the degree of freedom and to avoid the potential problem of multicollinearity (Tahir \& Norulazidah, 2013). The instrumentation strategy adopted by Romalis (2007), which is based on the liberalization process of developed countries is also appropriate and hence could be used in future research work. In a recent comprehensive paper (Bruckner \& Lederman, 2012) have constructed two instruments for the openness of Sub-Saharan Africa based on rainfall and the GDP growth of OECD economies. Further their results show that both the instruments are relevant and valid. It follows that various options and guidelines are available to the potential researchers to deal with the issue of endogeneity.

\subsection{Sample Selection}

It would be useful to investigate the impact of trade openness on economic growth using homogenous samples. The division of sample between developed and developing countries may not uncover the true relationship 
between trade openness and economic growth. Rather the sub-grouping of developing and developed countries based on per capita income is required to see how the observed relationship between trade openness and economic growth varies for different set of countries. Greenaway et al., (2002) have argued that varying sample sizes and composition coupled with varying methodological approaches could explain why the evidence regarding the growth effects of liberalization is inconsistent. Ackah (2008) has shown that tariffs appear to be related positively with economic growth for low-income countries while negatively correlated with economic growth for middle-income and richer countries. More to the point, Sarkar (2007) and Shamsadini et al., (2011) and Dowrick and Golley have also shed some shed some light on the trade-growth relationship of different group of countries. This kind of exercises not only reveals the exact relationship but may also allow generalization on limited basis.

\subsection{Quality of Data}

Regarding the quality of the data, it is utmost important to ensure the reliability of the data in order to get reliable estimates which in turn can be used for policy making. The World Bank, IMF, OECD and the Penn World Tables provide better quality data for research which are used frequently in cross-country growth analysis. However, researchers, who search for the links between trade openness and economic growth in particular economies (case studies), should also utilize data from the standard sources. This may prevent them from depending on government and state agencies where reliability of data is questionable. It is a general observation that governments in the less-developing countries try to manipulate the data through their influence on state agencies because they do not want to show the true picture of the economy to the international community.

\section{Concluding Remarks}

This survey paper studied the state of art of the relationship between trade openness and economic growth investigated in the literature. Influential papers that have dealt with the trade-growth relationship during the last couple of decades are analyzed. The objective was to see what has been done so far and what could be done next regarding the trade-growth relationship.

In this paper, it is concluded that the available literature provides an affirmative answer to the question whether or not there is a positive relationship between trade openness and economic growth. We agree with other researchers such as Krueger and Berg (2003) and Winters (2004) and Babula and Anderson (2008) about the measurement and methodological issues which are existing in the available literature. However, it shall also be noted that the presence of econometric and measurement problems does not reject the observed positive link between trade openness and economic growth. Future, research work is needed to address the contending issues in order to overcome the observed disagreements regarding the relationship between trade openness and economic growth. Various alternative solutions are available to existing flaws in the literature. Efforts should be made by researchers to opt for the best measure of openness among other available measures. However, it is not a simple task. The reliability of data, endogeneity, sample heterogeneity and the existence of a possible non-linear link between trade openness and economic growth need attention of the researchers to obtain reliable estimates. It is suggested that future research should also look for new tools of analysis in order to pick up the strong or marginal information in the data. In addition, the research needs to focus on the exact mechanism by which trade can influence economic growth as suggested by Hallak and Levinsohn (2004). Paying particular attention to the mentioned problems would eventually help researchers to establish an explicit relationship between trade openness and economic growth.

\section{Acknowledgements}

We are thankful to the Universiti Brunei Darussalam for providing necessary funding for this research under the GRS. We would also like to thank Dr. Nandana Goonewardena from the University of Papua New Guinea for his excellent guidance and suggestions.

\section{References}

Ackah, C. (2008, November). For Richer or Poorer: Trade Policy and Growth in Developing Countries. Paper Prepared for the UNECA Ad-hoc Expert Group Meeting on Macroeconomic Policy Productive Capacity and Growth in Africa, Addis Ababa.

Alcala, F., \& Ciccone, A. (2003). Trade, Extent of the Market, And Economic Growth 1960-1996. Departament d'Economica i Empresa, UPF; 765 .

Babula, R., \& Anderson, L. (2008). The Link Between Openness and Long-Run Economic Growth. Journal of International Commerce and Economics, 1-20. 
Bhagwati, J., \& Srinivasan, N. (2001). Outward-Orientation and Development: Are Revisionists Right? Economic Growth Center, Discussion Paper No. 806.

Brückner, M., \& Lederman, D. (2012). Trade Causes Growth in Sub-Saharan Africa. The World Bank Policy Research Working Paper No. 6007. http://dx.doi.org/10.1596/1813-9450-6007

Chang, R., Kaltani, L., \& Loayza, N. (2005). Openness can be Good for Growth: The Role of Policy Complementarities. Paper Presented in Conference at Central Bank of Peru (2005).

Cuadros, A., Orts, V., \& Alguacil, M. (2004). Openness and Growth: Re-Examining Foreign Direct Investment, Trade and Output Linkages in Latin America. The Journal of Development Studies, 40(4), 167-192. http://dx.doi.org/10.1080/00220380410001673238

Das, K. D. (2002). Trade Liberalization and Industrial Productivity: An Assessment of Developing Country Experiences. Indian Council for Research on International Economic Relations, Working Paper No. 77.

Dava, E. (2012). Trade Liberalization and Economic Growth in the SADC: A difference-in-difference alnalysis. "MOÇAMBIQUE: ACUMULAÇÃO E TRANSFORMAÇÃO EM CONTEXTO DE CRISE INTERNACIONAL" Conference Paper n ${ }^{\circ} 08$.

David, H. L. (2008). So You Want to Use a Measure of Trade Openness? In K. Banaian, B. Roberts, P. Macmillan, \& L. H. David (Eds.), The Design and Use of Political Economy Indicators.

Dollar, D. (1992). Outward-Oriented Economies Really Do Grow More Rapidly: Evidence from 95 LDCs. Economic Development and Cultural Change, 40(3), 523-544. http://dx.doi.org/10.1086/451959

Dollar, D., \& Kraay, A. (2002). Trade, growth, and poverty. Economic Journal, 114(493), F22-F49. http://dx.doi.org/10.1111/j.0013-0133.2004.00186.x

Dowrick, S., \& Golley, J. (2004). Trade Openness and Growth: Who Benefits? Oxford Review of Economic Policy, 20(1), 38-56. http://dx.doi.org/10.1093/oxrep/grh003

Edwards, S. (1998). Openness, Productivity and Growth: What Do We Really Know? The Economic Journal, 108, 383-398. http://dx.doi.org/10.1111/1468-0297.00293

Fiestas, I. (2005). The effects of trade liberalization on growth, poverty and inequality. CILAE Nota técnica $N T / 04 / 05$.

Frankel, A. J., \& Romer, D. (1999). Does Trade Cause Growth? The American Economic Review, 89(3), 379-399. http://dx.doi.org/10.1257/aer.89.3.379

Greenaway, D., Morgan, W., \& Wright, P. (2002). Trade liberalisation and growth in developing countries. Journal of Development Economics, 67, 229-244. http://dx.doi.org/10.1016/S0304-3878(01)00185-7

Hallak, C., \& Levinsohn, J. (2004). Fooling Ourselves: Evaluating The Globalization and Growth Debate. NBER Working Paper No. 10244.

Huchet-Bourdon, M., Mouel, L. C., \& Vijil, M. (2011). The Relationship between Trade Openness and Economic Growth: Some New Insights on the Openness Measurement Issue. XIIIeme Congres de I'Association Europeenne des Economistes Agricoles (EAAE), pp. 1-17.

Jones, I, C. (2000). Comments on Rodriguez and Rodrik, "Trade Policy and Economic Growth: A Skeptics Guide to the Cross-National Evidence. Comment prepared for presentation at the Macroeconomics Annual Conference, April 7-8, 2000 in Cambridge, Massachusetts.

Krueger, A., \& Berg, A. (2003). Trade, Growth and Poverty: A Selective Survey. IMF Working Paper No. 03/30.

Lopez, A. (2005). Trade and Growth: Reconciling the Macroeconomic and Microeconomic Evidence. Journal of Economic Surveys, 19(4), 623-648. http://dx.doi.org/10.1111/j.0950-0804.2005.00264.x

Mendoza, U. R. (2009). Trade and Growth in the Post - 2008/2009 Crisis World. World Economics, 11(4).

Noguer, M., \& Siscart, M. (2005). Trade raises income: A precise and robust result. Journal of International Economics, 65, 447-460. http://dx.doi.org/10.1016/j.jinteco.2003.11.006

Panagariya, A. (2004). Miracles and Debacles: In Defence of Trade Openness. World Economy, 27(8). http://dx.doi.org/10.1111/j.1467-9701.2004.00650.x

Rodríguez, F. (2007). Openness and Growth: What Have We Learned? DESA Working Paper No. 51.

Rodriguez, F., \& Rodrik, D. (2000). Trade Policy and Economic Growth: A Skeptics Guide to the Cross-National Evidence. NBER Working Paper No. 7081. 
Romalis, J. (2007). Market Access, Openness and Growth. NBER Working Paper No. 13048.

Sach, D. J., \& Warner, A. (1995). Economic Reforms and The Process of Global Integration. Brooking Papers on Economic Activity; 1995;1; ABI/ INFORM GLOBAL. http://dx.doi.org/10.2307/2534573

Sarkar, P. (2007). Trade Openness and Growth: Is there any Link? MPRA Paper No. 4997.

Shamsadini, S., Moghaddasi, R., \& Kheirandish, M. (2010). Relationship Between Trade Openness and GDP Growth a Panel Data Approach. World Applied Sciences Journal, 8(7), 906-911.

Stone, S., \& Strutt, E. A. (2009). Transport Infrastructure and Trade Facilitation in the Greater Mekong Subregionde. ADB Working Paper No. 130.

Tahir, M., Norulazidah, D. H., \& Omar Ali, P. H. (2013).The Relationship between Trade and Income: The Case of Developed Countries. International Research Journal of Finance and Economics, (111), 138-145.

Ulaşan, B. (2012). Openness to International Trade and Economic Growth: A Cross-Country Empirical Investigation. Economics, 1-58.

Wacziarg, R., \& Welch, H. K. (2003). Trade Liberalization and Economic Growth: New Evidence. NBER Working Paper No. 10152, 22(2), 187-231.

Walde, K., \& Wood, C. (2004). The empirics of trade and growth: Where are the policy recommendations? International Economics and Economic Policy, 1, 275-292. http://dx.doi.org/10.1007/s10368-004-0016-7

Warner, A. (2003). Once more in to the Breach: Economic Growth and Integration. Center for Global Development, Working Paper No. 34.

Willard, L. (2000). Does Openness Promote Growth? Agenda, 7(3), 251-261.

Winters, A. (2004). Trade Liberalization and Economic Performance: An Overview. The Economic Journal, 114, F4-F21. http://dx.doi.org/10.1111/j.0013-0133.2004.00185.x

\section{Copyrights}

Copyright for this article is retained by the author(s), with first publication rights granted to the journal.

This is an open-access article distributed under the terms and conditions of the Creative Commons Attribution license (http://creativecommons.org/licenses/by/3.0/). 